\title{
Role of Melatonin to Enhance Phytoremediation Capacity
}

\author{
Marino B. Arnao *(D) and Josefa Hernández-Ruiz \\ Department of Plant Biology (Plant Physiology), Faculty of Biology, University of Murcia, 30100-Murcia, Spain; \\ jhruiz@um.es \\ * Correspondence: marino@um.es
}

Received: 4 November 2019; Accepted: 2 December 2019; Published: 4 December 2019

\begin{abstract}
Phytoremediation is a green technology that aims to take up pollutants from soil or water. Metals are one of the targets of these techniques due to their high toxicity in biological systems, including plants and animals. Their elimination or, at least, decrease will help keep them from being incorporated in the trophic chain and thus reaching animal and human food. The metal removal efficiency of plants is closely related to their growth rate, tolerance, and their adaptability to different environments. Melatonin ( $\mathrm{N}$-acetyl-5-methoxytryptamine) is a ubiquitous molecule present in animals, plants, fungi, and bacteria. In plants, it plays an important role related to antioxidant activity, but also as an important redox network regulator. Thus, melatonin has been defined as a biostimulator of plant growth, especially under environmental stress conditions, whether abiotic (water deficit and waterlogging, extreme temperature, UV radiation, salinity, alkalinity, specific mineral deficit/excess, metals and other toxic compounds, etc.) or biotic (bacteria, fungi, and viruses). Exogenous melatonin treated plants have been seen to have a high tolerance to stressors, minimizing possible harmful effects through the control of reactive oxygen species (ROS) levels and activating antioxidative responses. Furthermore, important gene expression changes in stress specific transcription factors have been demonstrated. Melatonin is capable of mobilizing toxic metals, through phytochelatins, transporting this, while sequestration adds to the biostimulator effect of melatonin on plants, improving plant tolerance against toxic pollutants. Furthermore, melatonin improves the uptake of nitrogen $(\mathrm{N})$, phosphorus (P), and sulfur (S) in stress situations, enhancing cell metabolism. In light of the above, the application of melatonin seems to be a useful option for clearing toxic pollutants from the environment by improving phytoremediation. Interestingly, a variety of stressors induce melatonin biosynthesis in plants, and the study of this endogenous response in hyperaccumulator plants may be even more interesting as a natural response of the phytoremediation of diverse plants.
\end{abstract}

Keywords: abiotic stress; biostimulators; cadmium; cobalt; copper; heavy metals; lead; nickel; plant growth promoters; zinc

\section{Introduction}

Phytoremediation may be described as a technology that uses the ability of certain plants, known as hyperaccumulators, to take up pollutants from soil or water. Phytoremediation is of particular interest because it is a promising green technology, low cost, and eco-friendly [1]. However, hyperaccumulator plants are rare, and generally, their slow growth and small biomass limits their efficiency for phytoremediation purposes. The hyperaccumulator plants used for phytoremediation mainly accumulate metals in the shoot rather than the root [2]. Compared with non-accumulator plants, hyperaccumulating plants can concentrate 100 to 1000 times more heavy metals such as copper $(\mathrm{Cu})$, zinc $(\mathrm{Zn})$, cobalt $(\mathrm{Co})$, manganese $(\mathrm{Mn})$, nickel $(\mathrm{Ni})$, and lead $(\mathrm{Pb})$ [3]. Each plant species acts in a specific way in phytoremediation, taking up heavy metals by many mechanisms, including 
accumulation, exclusion, translocation, osmoregulation, and distribution. Of these, the most common is via the accumulation, translocation, and concentration of heavy metals in the aerial parts [4].

Various processes have been used as phytoremediation techniques, including phytoextraction, phytodegradation, rhizofiltration, phytostabilization, phytovolatilization, phytodesalination, and phytofiltration [5]. Phytoremediation can be carried out on site, thus reducing exposure risks for cleanup personnel or secondary contamination during transport. However, the physical, chemical, and biological properties of mine tailings (or other contaminated soils) may limit plant growth and their subsequent use in agriculture [6]. Three major phytoremediation techniques can be distinguished, depending on different plant properties: phytoextraction, phytostabilization, and phytovolatilization [7]. In the first method, plants are used to take up contaminants or metals via their roots. This type of extraction involves the accumulation or hyperaccumulation of metals in the above ground plant biomass. Contaminants or metals are then stored in the harvestable parts of plants and disposed of as hazardous waste or incinerated for metal recovery. In the case of phytostabilization, plants are used as a vegetation "cap" to not only reduce the mobility and bioavailability of contaminants in the natural environment, but also the availability for entry into the human food chain. The plant canopy serves to reduce air dispersion, while plant roots prevent water erosion, immobilize heavy metals, and prevent leaching. Thus, phytostabilization is a promising technique for the long term stabilization of tailings by creating a vegetation cap. Finally, phytovolatilization involves plants taking up pollutants (including organic contaminants) together with water and releasing them into the atmosphere through the stomata; some of these pollutants pass through the plants and reach the leaves and thereby evaporate into the atmosphere [8,9].

In constructed wetlands, the interaction between water/soil, plants, and microorganisms occurs through chemical, physical, and biological processes. A wide range of wastewaters such as municipal, industrial, agricultural, and storm waters can be remediated in constructed wetlands. The efficiency of heavy metal uptake by the plants they contain has been demonstrated [10]. The rate of metal removal by plants varies widely and is related to plant growth rate, plant species, and the concentration of heavy metals in the wastewater [11]. In wetlands constructed for phytoremediation or wastewater treatment, the residence time of metals in plants and the potential release of metals closely depend on the distribution of metals within the plants. Artificial floating islands, another type of constructed wetlands, are a soil-less planting structure constructed with floating mats, floating aquatic plants, sediment rooted emergent wetland plants, and related ecological communities. In pilot studies, this system was seen to improve the quality of polluted waters by removing organic matter, suspended solids, nutrients, and metals [12].

For the above described systems, aquatic plant species are of interest for use in phytoremediation processes because they can accumulate more than 1450-fold the concentration of the heavy elements in water [13]. In free-floating macrophytes, the entire plant body is above water except the roots, while in submerged macrophytes, the whole plant body remains submerged in water. For their part, emergent macrophytes are plants rooted in soil, but which emerge to reach significant heights above the water. A wide range of wetland plant species, such as water hyacinths Eichhornia spp., Salvinia spp., water lettuce (Pistia stratiotes), giant duckweed, duckweed (Lemna minor), and Azolla spp., submerged species such as Potamogeton spp. and Myriophyllum spp., and emergent species like Typha spp., Scirpus spp., Limnocharis flava, Spartina spp., Cyperus spp., and Phragmites spp. have shown their potential for removing metals from various type of wastewaters [14,15]. An extensive web-list of plant hyperaccumulators, classified by the metals they absorb, can be consulted [16].

Selecting the appropriate plant species is one of the most important considerations in the phytoremediation process. The plant species chosen should be capable of tolerating high metal levels and extreme soil conditions, such as high acidity, salinity, or alkalinity [17]. In addition, plants for revegetation should have other favorable attributes such as dense rooting systems, relatively fast growth rates, and high biomass production [7]. Furthermore, in semiarid mining regions, plant species 
should also be able to adapt to drought. Metal tolerant native plants are usually selected because they demonstrate tolerance to local environmental conditions and usually grow well and proliferate [18].

Suitable plants for phytoremediation can be divided into two groups based on their function: metal hyperaccumulators and biomass producers $[19,20]$. Metal hyperaccumulators are plants that exhibit higher levels of metal ion absorption in their tissues, but usually do not produce a high amount of biomass and have a slow growth rate. Brassicaceae spp. are known to have exceptionally high metal accumulating capacities [21]. Some authors have reported that Thlaspi species (typical hyperaccumulators) can accumulate over $1 \% \mathrm{Zn}, 0.1 \% \mathrm{Ni}$, and $0.1 \% \mathrm{Cd}$ in dry tissues. In addition, other heavy metals, including arsenic (As), $\mathrm{Cu}, \mathrm{Co}, \mathrm{Mn}$, and $\mathrm{Pb}$, can potentially be hyperaccumulated from mine tailings $[19,20]$. Biomass producers include plants that have a high biomass production and growth rate, but a relatively low metal uptake capacity, such as Brassica juncea (Indian mustard) [21].

Nutrient shortages are one of the main limitations of plants used for phytoremediation in mining areas, so it is generally necessary to amend the soils. Other biotechniques include: (i) enrichment with microorganisms, which can play an important role in solubilizing minerals such as $\mathrm{P}$ and potassium (K), releasing nutrients, and supplying them to plants through in situ bioremediation processes [22]; (ii) the use of metabolites such as organic acids, amino acids, and vitamins, which have also been demonstrated to enhance plant growth [23]; (iii) the addition of plant hormones, siderophores, and some enzymes synthesized by microorganisms, which may help plant growth [24-26]. In general, plants inoculated with plant growth promoting bacteria (PGPB) accumulate greater amounts of heavy metals than non-inoculated plants [27].

\section{How Can Melatonin Contribute in a More Efficient Phytoremediation?}

Decarboxylation of aromatic amino acids by specific decarboxylases leads to the production of starter compounds for the biosynthesis of secondary metabolites involved in stress resilience mechanisms [28]. More in particular, plant tryptophan decarboxylase (TDC) converts tryptophan into tryptamine [28], the precursor of N-acetyl-5-methoxytryptamine, known commonly as melatonin [29]. The protective effect of melatonin against abiotic stress situations in plants has been widely studied. Melatonin acts as an effective free radical scavenger against harmful reactive molecules, both reactive oxygen (ROS) and reactive nitrogen (RNS) species, such as hydroxyl radical, superoxide anion, singlet oxygen, hydrogen peroxide, hypochlorous acid, nitric oxide, peroxynitrite anion, peroxynitrous acid, and lipid peroxyl radicals, among others. The excellent properties of melatonin as an in vivo antioxidant against ROS/RNS, the absence of pro-oxidant effects, and the cascade antioxidant effect of melatonin related compounds have been the objective of a great number of researchers [30]. Melatonin is a more effective antioxidant than vitamin $C$ and $E$, with a scavenging activity 4-6 fold higher [31]. Furthermore, the amphipathic properties of melatonin permit it to scavenge free radicals in both hydrophilic and lipophilic media [30,32-38]. This direct chemical action of melatonin with ROS and RNS has been referred to as a receptor independent action [39].

In addition to this direct action, melatonin is capable of inducing many changes in gene expression. Melatonin changes the expression of a great number of gene elements in different physiological situations both in plant and animal cells [40-42]. Among the most studied melatonin mediated aspects in plants are the responses to abiotic stress (heat, cold, drought, salinity, alkalinity, heavy metals, and other toxic agents such as herbicides, fungicides, diverse contaminants) and biotic stress (fungi, virus, and bacteria). Furthermore, processes such as foliar senescence, growth and development, germination, rooting induction, flowering, parthenocarpy, fruit set, and fruit ripening were studied. Others aspects, such as photosynthesis and its regulation, primary and secondary metabolism, including osmoregulation, and the regulation of plant hormones (auxin, gibberellins, cytokinins, abscisic acid, ethylene, jasmonates, salicylic acid, polyamines, brassinosteroids, strigolactones) have been also analyzed [41,43-49].

In general, melatonin induces several gene expression changes in plants that result in a biostimulating response [41]. Due to the diversity of its actions, melatonin has been proposed 
as a plant master regulator, but also as a new plant hormone since its receptor (PMTR1) has been identified in Arabidopsis [41,50]. Melatonin acts as a main regulator of the redox network in plants, controlling directly and indirectly the ROS/RNS levels and the gene expression of many factors through the nitric oxide signaling cascade, among other pathways [51]. As a result, melatonin regulates redox network homeostasis, balancing several ROS and RNS and related key enzyme expressions (NOS-like, $\mathrm{NR}$, RbOHs, ASA-GSH cycle, antioxidant enzymes). It is also one of the main intermediates in many cellular and physiological responses, as is depicted in the integrative model of Figure 1.

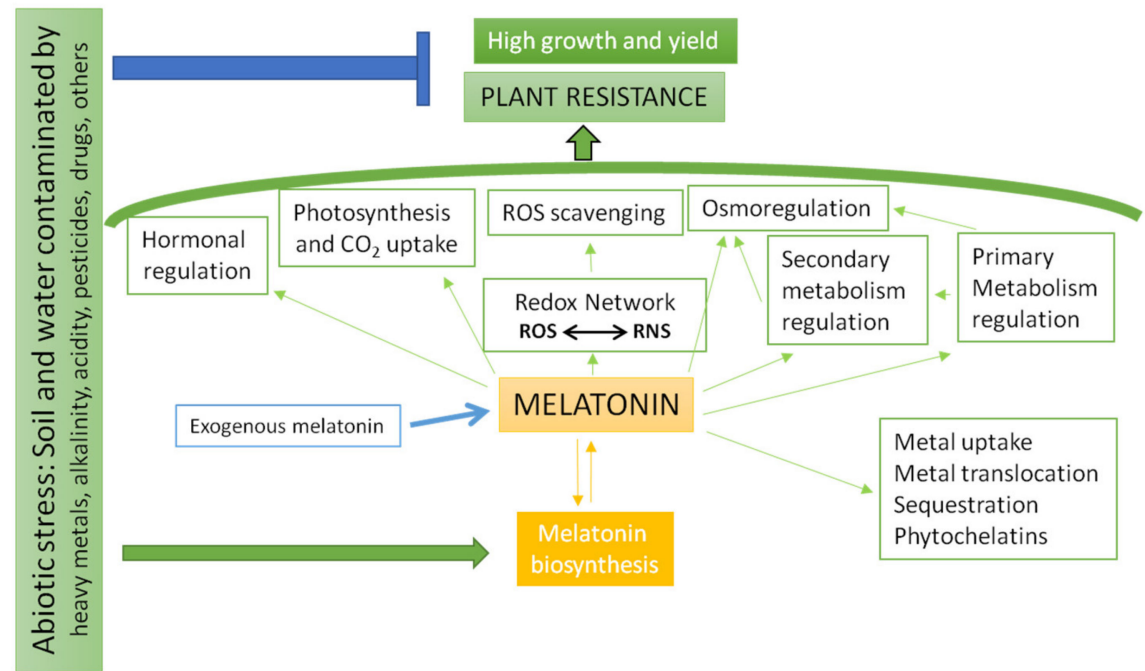

Figure 1. Model of the redox network regulated by melatonin and the effect of abiotic stressors.

\section{Metals as a Severe Abiotic Stress and Effects Induced by Melatonin in Plants}

The metal removal efficiency of plants is highly related to their growth rate, tolerance to high levels of metals, and adaptability to different environments. Melatonin is widely distributed among different plants, including hyperaccumulators such as water hyacinth, sunflower, mustard plants, radish, etc. [43], which suggests a probable role in phytoremediation, especially due to its high levels.

Table 1 shows several studies with metals and the effects observed by exogenous melatonin treatment. Furthermore, several studies with transgenic plants overexpressing melatonin biosynthesis genes, which extra-accumulate endogenous melatonin, have been made [44].

Several metals and non-metal elements have been used to study the resistance, tolerance, mobilization, accumulation, and diverse metabolic and physiological changes that occur in plants treated with melatonin compared with control plants. The first report related to phytoremediation and melatonin was published by Tan and co-workers (2007), who observed high contents of melatonin and melatonin by-products in water hyacinth [52]. The capacity of these plants to tolerate high levels of toxic pollutants was proposed. In a related study, the tolerance of pea plants to copper $(\mathrm{Cu})$ significantly improved after supplementation with melatonin [53].

Cadmium (Cd) has been the most widely assayed heavy metal in melatonin treated plants of several different species (Table 1). In general, melatonin treatment increases Cd tolerance, plant growth, and photosynthesis efficiency compared with non-treated plants. Furthermore, their water content and ion homeostasis were improved. Antioxidant enzymes increased and the ASA-GSH cycle improved, while ROS and MDA contents were reduced, optimizing the redox balance. Cd transport increased with the phytochelatin content in alfalfa and tomato, where the $\mathrm{Cd}$ content tended to accumulate in different locations (roots, stems, leaves, shoots). When the effects of melatonin on growth and Cd uptake in Malachium aquaticum (Cd accumulator) and Galinsoga parviflora (hyperaccumulator) were studied, melatonin application significantly increased the $\mathrm{Cd}$ content in both plants in a concentration dependent form, suggesting melatonin could improve phytoremediation [54]. In Cyphomandra betacea, a South American fruit tree, $50 \mu \mathrm{M}$ melatonin increased the Cd contents in stems, leaves, and shoots in 
a soil cultivation experiment. Low levels of melatonin were seen to promote the growth of $C$. betacea seedlings and their $\mathrm{Cd}$ accumulation capacity [55]. Melatonin treated plants, in a combination of $\mathrm{Cd}$ with selenium (Se) or $\mathrm{Zn}$, also showed increased plant growth and higher antioxidative defenses than control plants. In an interesting experiment with tomato plants that over-produced melatonin, pre-treatment with different forms of Se significantly induced the biosynthesis of melatonin and its precursors (tryptophan, tryptamine, and serotonin) [56]. 
Table 1. Studies of responses to melatonin treatments in the presence of several metals (or others) by different plant species.

\begin{tabular}{|c|c|c|c|c|}
\hline Stress Type & Plant Species & Melatonin Treatment $(\mu \mathrm{M})$ & Effects Observed & Reference \\
\hline $\mathrm{Cd}$ & Alfalfa & $10-200$ & $\uparrow$ tolerance, growth, $\mathrm{Cd}$ transporters, $\downarrow$ Cd roots, ROS & [57] \\
\hline $\mathrm{Cd}$ & Rice & $\mathrm{MOE}^{*}$ & $\uparrow$ tolerance, growth, photosynthesis, redox balance, panicle number, grain yield & {$[58,59]$} \\
\hline $\mathrm{Cd}$ & Tomato & $25-500$ & $\uparrow \mathrm{Cd}$ tolerance, phytochelatins, ATPase activity & [60] \\
\hline $\mathrm{Cd}$ & Tomato & MOE & $\uparrow \mathrm{Cd}$ tolerance, heat-shock factor $\mathrm{A} 1 \mathrm{a}$, induced by melatonin & [61] \\
\hline $\mathrm{Cd}$ & Tomato & 25 & $\uparrow \mathrm{Cd}$ tolerance, melatonin biosynthesis, $\downarrow$ Cd leaf & [62] \\
\hline $\mathrm{Cd}$ & Tomato & 100 & $\begin{array}{c}\uparrow \mathrm{Cd} \text { tolerance, melatonin biosynthesis, } \mathrm{S} \text { uptake, } \mathrm{S} \text { assimilation, antioxidant enzymes, } \\
\text { PCs, GSH }\end{array}$ & [63] \\
\hline $\mathrm{Cd}$ & Wheat & 100 & $\uparrow$ tolerance, antioxidant enzymes, ASA, GSH, $\downarrow$ ROS & [64] \\
\hline $\mathrm{Cd}$ & Wheat & 50-100 & $\begin{array}{l}\uparrow \text { tolerance, plant growth, Chls, PSII maximum efficiency, } \mathrm{RWC}, \mathrm{K}^{+}, \mathrm{Ca}^{2+}, \downarrow \mathrm{ROS}, \mathrm{Cd} \text {, } \\
\text { MDA, NO }\end{array}$ & [65] \\
\hline $\mathrm{Cd}$ & $\begin{array}{l}\text { Malachium aquaticum and Galinsoga } \\
\text { parviflora }\end{array}$ & $100-200$ & $\uparrow$ tolerance, biomass, Chls, antioxidant enzymes, Cd shoots concentration dependent & [54] \\
\hline $\mathrm{Cd}$ & Cyphomandra betacea & $50-150$ & $\uparrow$ plant growth, $\mathrm{Cd}$ leaves, shoots, stems, antioxidant enzymes & [55] \\
\hline & Perilla frutescens & 100-200 & $\uparrow$ root and shoot biomass, Chls, antioxidant enzymes, soluble protein, $\mathrm{Cd}$ root and shoot & [66] \\
\hline $\mathrm{Cd} / \mathrm{Se}$ & Tomato & MOE & $\uparrow$ growth, photosynthesis, electrolyte leakage, phytochelatins, GSH, $\downarrow$ ROS, Cd leaf & [56] \\
\hline $\mathrm{Cd} / \mathrm{Zn}$ & $\begin{array}{l}\text { Valerian and } \\
\text { Lemon balm }\end{array}$ & 1000 & $\uparrow$ tolerance, plant growth, antioxidant enzymes & [67] \\
\hline $\mathrm{Cu}$ & Red cabbage & $1-100$ & $\uparrow$ germination, growth, $\downarrow$ membrane peroxidation & [68] \\
\hline $\mathrm{Cu}$ & Cucumber & 0.01 & $\uparrow$ tolerance, growth, Cu-sequestration, TCA, ATP, GSH, $\downarrow$ ROS & [69] \\
\hline $\mathrm{Cu}$ & Pea & 5 & $\uparrow$ plant survival & [53] \\
\hline $\mathrm{Zn}$ & Wheat & 1000 & $\uparrow$ tolerance, Chls, photosynthesis, Rubisco, ATPase & [70] \\
\hline $\mathrm{Al}$ & Soybean & $0.1-1$ & $\uparrow$ tolerance, root growth, antioxidant enzymes, osmoregulation, $\downarrow$ ROS & [71] \\
\hline $\mathrm{Al}$ & Arabidopsis & $1-10$ & $\uparrow$ tolerance, root growth, cell division & [72] \\
\hline $\mathrm{Pb}$ & Maize & $50-100$ & $\uparrow$ tolerance, growth, photosynthesis, Chls, RWC, K, Ca levels, $\downarrow$ ROS, MDA & [73] \\
\hline $\mathrm{Pb}$ & Bermudagrass & $20-100$ & $\begin{array}{c}\uparrow \text { tolerance, biomass, Chls, RWC, ASA, GSH, antioxidant enzymes, } \downarrow \text { ROS, lipid } \\
\text { peroxidation }\end{array}$ & [74] \\
\hline $\mathrm{V}$ & Watermelon & 0.1 & $\begin{array}{c}\uparrow \text { tolerance, growth, photosynthesis, antioxidant enzymes, } \downarrow \text { V level, } \mathrm{V} \text { transport, ROS, } \\
\text { MDA }\end{array}$ & [75] \\
\hline Boron & Pepper & 1 & 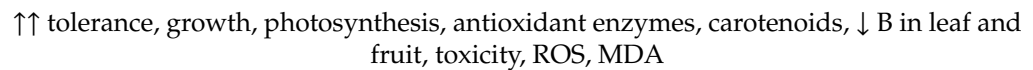 & [76] \\
\hline Boron & Spinach & $100-300$ & $\begin{array}{c}\uparrow \text { tolerance, growth, photosynthesis, } \mathrm{RWC}, \mathrm{CO}_{2} \text { uptake, sugars, carotenoids, redox } \\
\text { balance, } \downarrow \text { ROS, MDA }\end{array}$ & [77] \\
\hline Fluoride & Pigeon pea & 100 & $\begin{array}{c}\uparrow \text { tolerance, growth, antioxidant capacity, protein, proline, ASA, GSH, antioxidant } \\
\text { enzymes, genomic template stability, } \downarrow \text { ROS, cell death, lipid peroxidation, lipase } \\
\text { activity, DNA polymorphism }\end{array}$ & [78] \\
\hline Alkalinity & Apple & 5 & $\uparrow$ tolerance, root system, redox balance, polyamines & [79] \\
\hline Alkalinity & Tomato & $0.25-1$ & $\begin{array}{l}\uparrow \text { seedling growth, photosynthesis, ion homeostasis, } \mathrm{Na}^{+} \text {detoxification, dehydration } \\
\text { resistance, ROS homeostasis, } D R E B 1 \alpha \text { and IAA3 transcription factors }\end{array}$ & {$[80,81]$} \\
\hline
\end{tabular}


Table 1. Cont

\begin{tabular}{|c|c|c|c|c|}
\hline Stress Type & Plant Species & Melatonin Treatment $(\mu \mathrm{M})$ & Effects Observed & Reference \\
\hline Acid rain & Tomato & 100 & $\begin{array}{c}\uparrow \text { tolerance, growth, chloroplast integrity, photosynthesis, antioxidant enzymes, } \downarrow \text { ROS, } \\
\text { MDA }\end{array}$ & [82] \\
\hline Salinity, Fe-low & Pepper & 100 & $\uparrow$ growth, Chls, photosynthesis, fruit yield, Fe, $\mathrm{K}$ uptake, antioxidant enzymes & [83] \\
\hline Fe-low & Arabidopsis & 5 & $\begin{array}{c}\uparrow \text { melatonin, Fe shoots and roots, Fe mobilization, NO, polyamines, } \downarrow \text { chlorosis, Fe root } \\
\text { cell walls, ROS }\end{array}$ & [84] \\
\hline S-low & Tomato & 100 & $\begin{array}{c}\uparrow \mathrm{S} \text { uptake, assimilation, transport and metabolism, peroxiredoxins, redox homeostasis, } \\
\qquad \begin{array}{c}\text { ROS, DNA damage }\end{array}\end{array}$ & [85] \\
\hline N-low & Wheat & 1 & $\uparrow \mathrm{N}$ and nitrate, $\mathrm{N}$ absorption, $\mathrm{N}$ metabolism, growth, yield, in shoots and roots & [86] \\
\hline $\mathrm{N}$-excess & Cucumber & 100 & $\uparrow$ tolerance, growth, NPK balance, $\mathrm{Ca}, \downarrow$ damage, nitrate, ammonium & [87] \\
\hline Cinnamic acid & Cucumber & 100 & $\uparrow$ tolerance, growth, water and nutrient balance, hormonal balance & [88] \\
\hline Butafenacil & Rice & MOE & $\uparrow$ herbicide tolerance, Chls, antioxidant enzymes, $\downarrow$ ROS, MDA & [89] \\
\hline Fluopicolide & Potato & $1-10$ & $\uparrow$ fungicide tolerance, $\downarrow$ ROS, potato late blight, mycelial growth of $P$. infestans & [90] \\
\hline Paraquat & Pea & $50-200$ & $\uparrow$ Chls, porphyrin synthesis pathway, $\downarrow$ herbicide damage, Chl breakdown & [91] \\
\hline Carbendazim & Tomato & $0.5 / \mathrm{MOE}$ & $\uparrow$ fungicide tolerance, antioxidant enzymes, ASA-GSH cycle, $\downarrow$ ROS, MDA & [92] \\
\hline
\end{tabular}

$\uparrow$, Increased content or increased action. $\downarrow$, Decreased content or decreased action. ${ }^{*} \mathrm{MOE}$, melatonin biosynthesis enzymes overexpressed in plants. 
Selenocysteine had the most marked effect on melatonin biosynthesis. Se treatment increased the levels of glutathione (GSH) and phytochelatins, as well as the expression of GSH and phytochelating biosynthetic genes in non-silenced plants, but the effects of Se were lessened in TDC silenced plants (low melatonin content) under Cd stress. Furthermore, Se and melatonin supplements significantly increased plant $\mathrm{Cd}$ tolerance, optimizing plant growth parameters. Thus, exogenous selenocysteine could ameliorate $\mathrm{Cd}$ phytotoxicity, but a basal level of endogenous melatonin is required for Se conferred Cd tolerance, which might enhance the detoxification of Cd (Table 1) [56].

Copper $(\mathrm{Cu})$ salts have also been used to study the protective and biostimulatory effect of melatonin (Table 1). In addition to its known effect on the germination of seeds in the presence of $\mathrm{Cu}$, which was one of the first roles of melatonin discovered [68,93], low levels of melatonin provide greater tolerance of the presence of $\mathrm{Cu}$ in cucumber plants. Melatonin induces metabolic activity, especially glycolysis and the pentose phosphate pathway, to generate more ATP. Melatonin treatment broadly altered gene expression under $\mathrm{Cu}$ stress, increasing the levels of GSH and phytochelatin to chelate excess $\mathrm{Cu}$ and promoting cell wall trapping, retaining more $\mathrm{Cu}$ in the cell wall and vacuole [69]. Furthermore, some experiments have been made using zinc, aluminum, and lead in wheat, soybean, Arabidopsis, and maize (Table 1).

Vanadium (V) adversely affects plant growth through drastic changes in cellular metabolism, including gene expression and ROS production. Higher levels of $V$ affect root growth and the formation of lateral roots and provokes leaf chlorosis. Vanadium is a chemical analogue of phosphorus $(\mathrm{P})$ and alters the $\mathrm{P}$ absorption capacity of plants $[94,95]$. In a recent study, melatonin pretreatment lowered leaf and stem $\mathrm{V}$ concentrations by reducing $\mathrm{V}$ transport from root to shoot in watermelon (Table 1 ). In V treated plants, melatonin also renewed plant growth and increased photosynthesis efficiency; the antioxidant enzyme pool was also improved. Taken together, this evidence underlines the protective role of melatonin in increasing $\mathrm{V}$ tolerance [75].

Boron (B) is an essential micronutrient for normal plant growth, but high concentrations are toxic for plants. Boron has also been assayed in the presence of melatonin (Table 1). In pepper plants whose roots were exposed to a high $B$ concentration $(100 \mu \mathrm{M})$, melatonin treatment restored plant growth and photosynthesis compared with control plants. Plants treated with melatonin displayed no visible B toxicity symptoms, and leaves and fruits showed moderate B accumulation and high carbohydrate, carotenoid, and flavonoid contents. The authors took this as a demonstration of the clear protective activity of melatonin in reducing B absorption, suggesting its physiological relevance in B homeostasis [76]. Similar results and conclusions have been obtained in spinach plants exposed to high B concentrations (Table 1).

Higher concentrations of fluoride ions $\left(\mathrm{F}^{-}\right)$in the soil and irrigation water can disturb both the physiological and biochemical processes of plants [96]. Melatonin acts as an ROS scavenger, improving many biochemical parameters in pigeon pea (Cajanus cajan) (Table 1), helping in diminishing $\mathrm{F}^{-}$ toxicity [78].

Although soil alkalization is often associated with soil salinity, the former is considered much more hazardous to plants. This condition is generally linked with high $\mathrm{pH}$ stress and sodium toxicity caused by an excess of $\mathrm{Na}_{2} \mathrm{CO}_{3}$ and $\mathrm{NaHCO}_{3}$ in the soil, as well as osmotic stress. The comprehensive stress caused by alkaline soils directly affects physiological homeostasis at the cellular and whole-plant levels [97]. In this context, melatonin has been seen to protect apple and tomato plants against alkalinization (Table 1). In the case of apple, exogenous melatonin enhanced tolerance to alkaline stress by regulating the biosynthesis of polyamines, while in tomato plants, a strong resistance to dehydration, $\mathrm{ROS}$ homeostasis, and $\mathrm{Na}^{+}$detoxification has been described [80,81]. In tomato also, melatonin treatment increased simulated acid rain (SAR) stress tolerance by repairing the grana lamella of the chloroplast, improving photosynthesis and antioxidant enzyme activities compared with the reactions recorded in SAR stressed plants without melatonin. Such positive effects of melatonin are concentration dependent [82]. 
The positive role of melatonin against soil mineral deficiency has been described in several works (Table 1), resulting in an improvement in chemical element deficiency tolerance. For example, $\mathrm{Fe}$ deficiency induced chlorosis in seedlings of Arabidopsis thaliana was alleviated by melatonin. Exogenous melatonin significantly increased the soluble Fe content of shoots and roots and decreased the levels of root cell wall Fe bound to pectin and hemicellulose, remobilizing cell wall $\mathrm{Fe}$ and alleviating $\mathrm{Fe}$ deficiency induced chlorosis. Furthermore, Fe deficiency quickly induced melatonin biosynthesis in Arabidopsis plants, acting synergistically with exogenous treatments. In mutant plants deficient in polyamine and nitric oxide (NO) biosynthesis, the protective role of melatonin was not observed, indicating that the process is dependent on the polyamine induced NO production under Fe deficient conditions [84]. In a similar work, tomato seedlings grown in an S deficient medium suffered serious growth inhibition as a result of a reduced chlorophyll content, photosynthesis, and biomass accumulation; it also led to cell structural alterations and DNA damage. Melatonin supplementation of $S$ deprived plants resulted in a significant diminution in ROS content, alleviating all the described symptoms. Melatonin promoted $\mathrm{S}$ uptake and assimilation by regulating the expression of genes encoding enzymes involved in $\mathrm{S}$ transport and metabolism, supporting a role for melatonin as a molecule that improves primary metabolism and redox homeostasis [85].

In winter wheat grown in an $\mathrm{N}$ deficient medium, the application of melatonin in hydroponic solution significantly improved seedling growth under both $\mathrm{N}$ sufficient and deficient conditions, but the effect of melatonin in promoting seedling growth was particularly evident in the $\mathrm{N}$ deficient conditions. Higher $\mathrm{N}$ contents and nitrate levels in shoot under $\mathrm{N}$ deficient conditions appeared and also maintained higher nitrate nitrogen levels in roots. Furthermore, nitrate reductase and glutamine synthetase activities were higher in melatonin treated plants under $\mathrm{N}$ deficiency conditions. In conclusion, melatonin is involved in promoting $\mathrm{N}$ uptake and assimilation through upregulating the activities of $\mathrm{N}$ uptake and metabolic related enzymes and, ultimately, promotes plant growth and yield, especially under $\mathrm{N}$ deficient conditions [86]. Melatonin also seems to play an important role in situations contrary to those described above. Excess nitrogen is generally applied so that adequate levels will be maintained in the rhizosphere. This abusive use, besides being a serious problem since it results in the contamination of aquifers, provokes disruption in the balance of elements and alters the assimilation of calcium and magnesium, affecting the susceptibility to disease. In general, nitrate accumulation leads to increased proline concentrations, severe oxidative damage, nitrogen metabolic disorders, the inhibition of photosynthesis, and a substantial decrease in biomass. The application of melatonin significantly improved the growth of cucumber plants and reduced their susceptibility to damage when grown in high nitrate levels. Although excess nitrate led to an increase in the concentrations of $\mathrm{N}, \mathrm{K}$, and $\mathrm{Ca}$, accompanied by a decrease in $\mathrm{P}$ and $\mathrm{Mg}$ levels, exogenous melatonin generally had the opposite effect, except for a further rise in Ca concentrations (Table 1). Pretreatment also significantly reduced the accumulations of nitrate (both $\mathrm{N}$ and ammonium) and enhanced the activities of the enzymes involved in nitrogen metabolism, thereby alleviating the inhibitory effect on growth normally associated with nitrate stress [87].

Another role of melatonin is as a biostimulator and alleviator of toxicity from herbicides and other chemicals (Table 1). For example, melatonin significantly attenuated potato late blight by inhibiting mycelial growth, changing the cell ultrastructure, and reducing the stress tolerance of the high pathogenic fungus Phytophthora infestans. Of particular note are the synergistic anti-fungal effects of melatonin and the fungicide Infinito (fluopicolide, Bayer ${ }^{\circledR}$ ) on P. infestans, suggesting that melatonin could reduce the dose levels and enhance the efficacy of the fungicide against potato late blight [90]. The same synergistic action of melatonin and ethylicin (a bio-oomyceticide fungicide) has been described [98]. A similar beneficial effect of melatonin treatments was observed with other fungicides and herbicides (Table 1). 


\section{Abiotic Stressors Induce a Melatonin Burst that Activates Anti-Stress Responses}

Endogenous melatonin levels change with environmental conditions of plant growth. Melatonin is accumulated as a protective molecule in response to different environmental abiotic stressors, such as water deficit and waterlogging, cold and heat, UV radiation, soil heavy chemicals and related, among others $[41,48,99]$. Table 2 shows some studies on the increase of endogenous melatonin levels by the presence of different abiotic stressors. Thus, the expression of the biosynthesis enzyme transcripts (TDC, SNAT, ASMT, and COMT genes) occurs in stress situations, producing a burst in the levels of endogenous melatonin. The global influence of environmental factors on the melatonin levels of plant organs was clearly demonstrated in barley, tomato, and lupin plants by Arnao and co-workers [99-101]. This effect was previously suggested in water hyacinth plants [52], and later corroborated in grape berry skin [102] and cherry fruits [103]. Salinity, cold, drought, and heavy metals have been the abiotic environmental agents most frequently studied as inducers of melatonin biosynthesis in plants, although attack by pathogens also induces the biosynthesis of melatonin (Table 2). This interesting response of stressed tissues clearly induces tolerance, fortifying the redox network against ROS and RNS and upregulating the expression of stress specific response genes. All this relieves the inhibitory processes due to stress and reinforces plant growth and critical processes such as photosynthesis, water economy, metabolism, etc. $[41,51,104,105]$. The remediation efficiency is directly correlated to higher biomass and an improved tolerance of plants to toxic pollutants. Studies made with melatonin suggested that the stimulatory effects of melatonin on biomass and antioxidative defense machinery are reinforced by a strong primary and secondary metabolism and also by plant hormone stress responses. Melatonin acts as a biostimulator and/or protector of photosynthesis and the stomatal apparatus, upregulating many elements of photosystems, thylakoid electron transporters, and ATP-ase genes. Melatonin also optimizes stomata functionality (e.g., by causing increased stomata opening) in adverse conditions through the regulation of guard cell anion channel proteins and dehydrins, all of which increase $\mathrm{CO}_{2}$ availability. In the Calvin cycle, melatonin regulates the expression of RuBisCO elements, glyceraldehyde-3-phosphate dehydrogenases, and interconversion carbohydrate enzymes. In addition, elements of the ASC-GSH cycle, TCA cycle, and myo-inositol and fatty acid biosynthesis pathways are also regulated by melatonin. As regards osmoregulation, higher levels of proline, carbohydrates (glucose, maltose, fructose, sucrose, and trehalose), and a multitude of amino acids and organic acids in melatonin treated plants had beneficial effects under abiotic stress conditions. Thus, relevant changes in carbohydrate, lipid, amino acid, nitrogen, phosphorus, and sulfur metabolism indicate the beneficial physiological processes that occur in melatonin treated plants during abiotic stress $[86,87,106-109]$. Melatonin is also involved in secondary metabolism, where it induces anthocyanin biosynthesis and flavonoids $[110,111]$ and also regulates steps in the carotenoid biosynthesis [76,112]. Finally, melatonin regulates the expression of multiple elements (enzymes, receptors, and transcription factors) in the biosynthesis, catabolism, and signaling of auxin, gibberellins, cytokinins, ABA, ethylene, jasmonic acid, SA, brassinosteroid, strigolactones, and polyamines $[41,46,48]$ (Figure 1). 
Table 2. Effects of abiotic stressors on the endogenous melatonin levels.

\begin{tabular}{|c|c|c|c|}
\hline Plant Species & Abiotic Stressor & $\begin{array}{l}\text { Increased Level of } \\
\text { Melatonin vs. Control }\end{array}$ & Reference \\
\hline Alfalfa & Waterlogging & 2-4.5-fold & [113] \\
\hline \multirow{5}{*}{ Arabidopsis } & Cold & 2-fold & [114] \\
\hline & Heat & 2-5-fold & [115] \\
\hline & $\mathrm{NaCl}$, drought, cold & 3-6-fold & [116] \\
\hline & Fe deficiency & 6-fold & [84] \\
\hline & Drought & 4 -fold * & [117] \\
\hline Barley & $\mathrm{Zn}, \mathrm{NaCl}, \mathrm{H}_{2} \mathrm{O}_{2}$ & 6-fold & [100] \\
\hline Barley & Drought, cold & 2-fold & [118] \\
\hline Bermudagrass & $\mathrm{NaCl}$, drought, cold & 2-3-fold & {$[106,119]$} \\
\hline Cassava & Bacterial blight & 1.2-4-fold * & [120] \\
\hline Cherry & Field growth conditions & 10-fold & [103] \\
\hline Grape & Field growth conditions & 15-fold & [102] \\
\hline Lupin & $\begin{array}{c}\mathrm{Zn}, \mathrm{NaCl}, \mathrm{H}_{2} \mathrm{O}_{2} \\
\text { Cold, drought }\end{array}$ & 1.5-12-fold & [99] \\
\hline Malus & Drought & 1.5-6-fold * & [121] \\
\hline \multirow[t]{2}{*}{ Rice } & $\mathrm{Cd}$ & 6 -fold & [122] \\
\hline & Cold, salt, drought, pathogen & $1.5-4.5$-fold * & [123] \\
\hline Ryegrass & Darkness & 2-fold & [124] \\
\hline Sunflower & $\mathrm{NaCl}$ & 2-6-fold & [125] \\
\hline \multirow[t]{5}{*}{ Tomato } & Field growth conditions & 10-fold & [101] \\
\hline & $\mathrm{Cd}$ & 1.6-4-fold & [62] \\
\hline & $\mathrm{Cd}$ & 2-fold & [60] \\
\hline & $\mathrm{Cd}$ & 2-15-fold * & [63] \\
\hline & High temperature & $2-15$-fold * & [126] \\
\hline \multirow{2}{*}{ Vitis } & $\mathrm{NaCl}$ & 5.5-fold & \\
\hline & Osmotic & 1.5 -fold & [127] \\
\hline Water hyacinth & Field growth conditions & 2-fold & [52] \\
\hline Watermelon & $\mathrm{V}$ & 4 -fold * & [75] \\
\hline
\end{tabular}

${ }^{*}$ Number of increments of one or more transcripts of melatonin biosynthesis enzymes due to stressor presence.

\section{Conclusions and Expectations}

The application of melatonin on plants seems to be a useful option for cleaning toxic pollutants from the environment by improving phytoremediation processes. In this capacity, three aspects should be taken into account: (i) the inhibitory effect of metals or toxic agents on growth and other basic functions such as metabolism and photosynthesis, (ii) the ability of cells to mobilize, absorb, and sequester the said agents, and (iii) other adverse elements that usually accompany the presence of contaminants such as drought, salinity, extreme temperatures, etc. The beneficial effects of melatonin described above were seen to cover all three cases. The potential of melatonin to mobilize toxic metals, through phytochelatins, their transport, and sequestration adds to the general biostimulatory effect of melatonin on plants, resulting in a high degree of plant tolerance against toxic substances (Figure 2). Furthermore, the improvement in the absorption and metabolism of elements such as N, P, and S helps the process. Although data are still limited, it seems that the presence of several stressors (e.g., metals and drought) synergistically induces the response of melatonin biosynthesis, which reinforces the overall response of the system. Beyond the use of transgenic plants that overaccumulate melatonin, the application of exogenous melatonin or the induction of its biosynthesis through environmental elicitors can be excellent strategies for phytoremediation purposes. There are clear benefits to be had from further studying the applicability of melatonin for phytoremediation purposes. As regards plant species, more research into the biochemical and physiological aspects of melatonin in hyperaccumulator plants is indispensable, furthering our knowledge of the synergistic effect of abiotic stressors on endogenous melatonin levels and its phytoremediation capacity. Furthermore, 
the modes of application of exogenous melatonin through the roots and/or through the leaves should be studied, although its amphipathic nature already means that we know that it is well absorbed at both sites (rhizosphere and leaves) without the need for adjuvants and that it is easily transported throughout the plant. Sufficient data are available to suggest the potential of melatonin to improve phytoremediation, but the last decisive step needs to be taken: testing in real field situations.

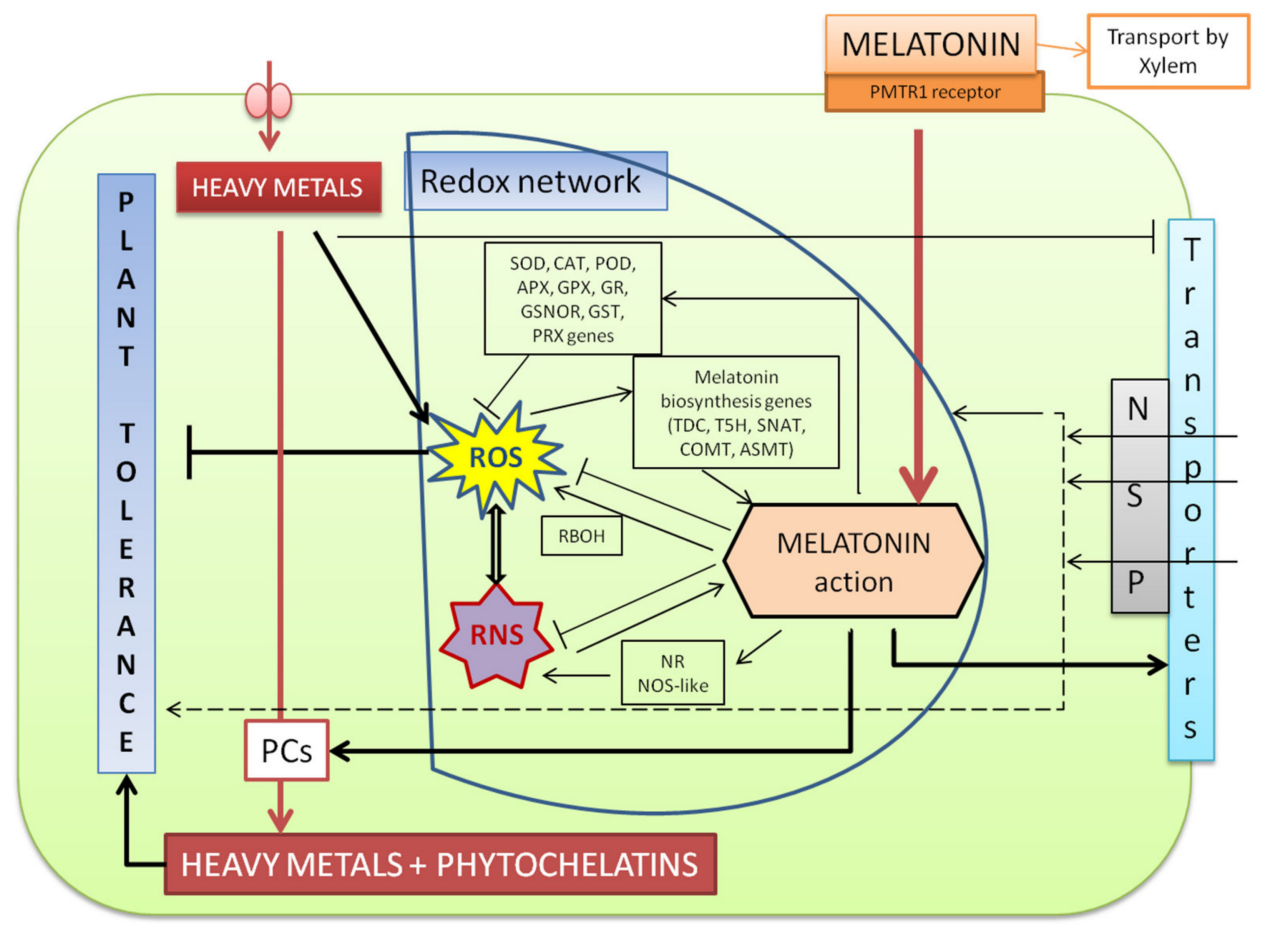

Figure 2. Integrated model of melatonin, the redox network, and phytochelatin (PCs) action focused on plant tolerance against heavy metal contaminants in plant cells.

Author Contributions: The manuscript was conceived by M.B.A. and written by M.B.A. and J.H.-R.

Funding: No external financial support available for this review.

Conflicts of Interest: The authors declare no conflicts of interest.

\section{References}

1. Liu, L.; Li, W.; Song, W.; Guo, M. Remediation techniques for heavy metal-contaminated soils: Principles and applicability. Sci. Total Environ. 2018, 633, 206-219. [CrossRef] [PubMed]

2. Singh, R.; Singh, D.P.; Kumar, N.; Bhargava, S.K.; Barman, S.C. Accumulation and translocation of heavy metals in soil and plants from fly ash contaminated area. J. Environ. Biol. 2010, 31, 421-430. [PubMed]

3. Sheoran, V.; Sheoran, A.S.; Poonia, P. Role of hyperaccumulators in phytoextraction of metals from contaminated mining sites: A review. Crit. Rev. Environ. Sci. Technol. 2010, 41, 168-214. [CrossRef]

4. Bhargava, A.; Carmona, F.F.; Bhargava, M.; Srivastava, S. Approaches for enhanced phytoextraction of heavy metals. J. Environ. Manag. 2012, 105, 103-120. [CrossRef] [PubMed]

5. Rahman, M.A.; Hasegawa, H. Aquatic arsenic: Phytoremediation using floating macrophytes. Chemosphere 2011, 83, 633-646. [CrossRef] [PubMed]

6. Wang, L.; Ji, B.; Hu, Y.; Liu, R.; Sun, W. A review on in situ phytoremediation of mine tailings. Chemosphere 2017, 184, 594-600. [CrossRef]

7. Marques, A.P.G.C.; Rangel, A.O.S.S.; Castro, P.M.L. Remediation of heavy metal contaminated soils: Phytoremediation as a potentially promising clean-Up technology. Crit. Rev. Environ. Sci. Technol. 2009, 39, 622-654. [CrossRef] 
8. Pulford, I.D.; Watson, C. Phytoremediation of heavy metal-contaminated land by trees review. Environ. Int. 2003, 29, 529-540. [CrossRef]

9. Mendez, M.O.; Maier, R.M. Phytoremediation of mine tailings in temperate and arid environments. Rev. Environ. Sci. Bio/Technol. 2008, 7, 47-59. [CrossRef]

10. Pedescoll, A.; Sidrach-Cardona, R.; Hijosa-Valsero, M.; Bécares, E. Design parameters affecting metals removal in horizontal constructed wetlands for domestic wastewater treatment. Ecol. Eng. 2015, 80, 92-99. [CrossRef]

11. Sheoran, A.S.; Sheoran, V. Heavy metal removal mechanism of acid mine drainage in wetlands: A critical review. Miner. Eng. 2006, 19, 105-116. [CrossRef]

12. Yeh, N.; Yeh, P.; Chang, Y.H. Artificial floating islands for environmental improvement. Renew. Sustain. Energy Rev. 2015, 47, 616-622. [CrossRef]

13. Fawzy, M.A.; Badr, N.E.; El-Khatib, A.; Abo-El-Kassem, A. Heavy metal biomonitoring phytoremediation potentialities of aquatic macrophytes in River Nile. Environ. Monit. Assess. 2012, 184, 1753-1771. [CrossRef] [PubMed]

14. Soda, S.; Hamada, T.; Yamaoka, Y.; Ike, M.; Nakazato, H.; Saeki, Y.; Kasamatsu, T.; Sakurai, Y. Constructed wetlands for advanced treatment of wastewater with a complex matrix from a metal-processing plant: Bioconcentration and translocation factors of various metals in Acorus gramineus and Cyperus alternifolius. Ecol. Eng. 2012, 39, 63-70. [CrossRef]

15. Rodríguez, M.; Brisson, J. Pollutant removal efficiency of native versus exotic common reed (Phragmites australis) in North American treatment wetlands. Ecol. Eng. 2015, 74, 364-370. [CrossRef]

16. Available online: https://en.wikipedia.org/wiki/List_of_hyperaccumulators (accessed on 4 December 2019).

17. Wu, Y.; Li, Y.; Zheng, C.; Zhang, Y.; Sun, Z. Organic amendment application influence soil organism abundance in saline alkali soil. Eur. J. Soil Biol. 2013, 54, 32-40. [CrossRef]

18. Santibañez, C.; de la Fuente, L.M.; Bustamante, E.; Silva, S.; León-Lobos, P.; Ginocchio, R. Potential use of organic-and hard-rock mine wastes on aided phytostabilization of large-scale mine tailings under semiarid Mediterranean climatic conditions: Short-term field study. Appl. Environ. Soil Sci. 2012, 2012, e895817. [CrossRef]

19. Robinson, B.H.; Leblanc, M.; Petit, D.; Brooks, R.R.; Kirkman, J.H.; Gregg, P.E.H. The potential of Thlaspi caerulescens for phytoremediation of contaminated soils. Plant Soil 1998, 203, 47-56. [CrossRef]

20. Moreno, F.N.; Anderson, C.W.N.; Stewart, R.B.; Robinson, B.H. Phytoremediation of mercury-contaminated mine tailings by induced plant-mercury accumulation. Environ. Pract. 2004, 6, 165-175. [CrossRef]

21. Belimov, A.A.; Hontzeas, N.; Safronova, V.I.; Demchinskaya, S.V.; Piluzza, G.; Bullitta, S.; Glick, B.R. Cadmium-tolerant plant growth-promoting bacteria associated with the roots of Indian mustard (Brassica juncea L. Czern.). Soil Biol. Biochem. 2005, 37, 241-250. [CrossRef]

22. Schmalenberger, A.; O'Sullivan, O.; Gahan, J.; Cotter, P.D.; Courtney, R. Bacterial communities established in bauxite residues with different restoration histories. Environ. Sci. Technol. 2013, 47, 7110-7119. [CrossRef] [PubMed]

23. Alexander, D.B.; Zuberer, D.A. Use of chrome azurol S reagents to evaluate siderophore production by rhizosphere bacteria. Biol. Fertil. Soils 1991, 12, 39-45. [CrossRef]

24. Glick, B.R.; Todorovic, B.; Czarny, J.; Cheng, Z.; Duan, J.; McConkey, B. Promotion of plant growth by bacterial ACC deaminase. Crit. Rev. Plant Sci. 2007, 26, 227-242. [CrossRef]

25. Asif, M.; Pervez, A.; Ahmad, R. Role of Melatonin and Plant-Growth-Promoting Rhizobacteria in the Growth and Development of Plants. CLEAN: Soil Air Water 2019, 47, 1800459. [CrossRef]

26. Yakhin, O.I.; Lubyanov, A.A.; Yakhin, I.A.; Brown, P.H. Biostimulants in Plant Science: A Global Perspective. Front. Plant Sci. 2017, 7, 2049. [CrossRef]

27. Ullah, A.; Heng, S.; Munis, M.F.H.; Fahad, S.; Yang, X. Phytoremediation of heavy metals assisted by plant growth promoting (PGP) bacteria: A review. Environ. Exp. Bot. 2015, 117, 28-40. [CrossRef]

28. De Masi, L.; Castaldo, D.; Pignone, D.; Servillo, L.; Facchiano, A. Experimental Evidence and in Silico Identification of Tryptophan Decarboxylase in Citrus Genus. Molecules 2017, 22, 272. [CrossRef]

29. Zhao, D.; Wang, R.; Liu, D.; Wu, Y.; Sun, J.; Tao, J. Melatonin and expression of tryptophan decarboxylase gene (TDC) in herbaceous peony (Paeonia lactiflora Pall.) flowers. Molecules 2018, 23, 1164. [CrossRef]

30. Tan, D.X.; Manchester, L.C.; Reiter, R.J.; Qi, W.B.; Karbownik, M.; Calvo, J.R. Significance of melatonin in antioxidative defense system: Reactions and products. Biol. Signals Recept 2000, 9, 137-159. [CrossRef] 
31. Tan, D.X.; Hardeland, R.; Manchester, L.C.; Poeggeler, B.; López-Burillo, S.; Mayo, J.C.; Sainz, R.S.; Reiter, R.J. Mechanistic and comparative studies of melatonin and classic antioxidants in terms of their interactions with the ABTS cation radical. J. Pineal Res. 2003, 34, 249-259. [CrossRef]

32. Reiter, R.J.; Paredes, S.D.; Manchester, L.C.; Tan, D.X. Reducing oxidative/nitrosative stress: A newly-discovered genre for melatonin. Crit. Rev. Biochem. Mol. Biol. 2009, 44, 175-200. [CrossRef] [PubMed]

33. Karbownik, M.; Reiter, R.J.; Qi, W.; Garcia, J.J.; Tan, D.X.; Manchester, L.C.; Vijayalaxmi. Protective effects of melatonin against oxidation of guanine bases in DNA and decreased microsomal membrane fluidity in rat liver induced by whole body ionizing radiation. Mol. Cell. Biochem. 2000, 211, 137-144. [CrossRef] [PubMed]

34. Reiter, R.J.; Tan, D.X.; Qi, W.; Manchester, L.C.; Karbownik, M.; Calvo, J.R. Pharmacology and physiology of melatonin in the reduction of oxidative stress in vivo. Biol. Signals Recept 2000, 9, 160-171. [CrossRef] [PubMed]

35. Romero, A.; Ramos, E.; de Los Ríos, C.; Egea, J.; del Pino, J.; Reiter, R.J. A review of metal-catalyzed molecular damage: Protection by melatonin. J. Pineal Res. 2014, 56, 343-370. [CrossRef]

36. Reiter, R.J.; Tan, D.X.; Galano, A. Melatonin: Exceeding expectations. Physiology 2014, 56, 371-381. [CrossRef]

37. Reiter, R.J.; Tan, D.X.; Galano, A. Melatonin Reduces Lipid Peroxidation and Membrane Viscosity. Front. Physiol. 2014, 5, 377. [CrossRef]

38. Teixeira, A.; Morfim, M.P.; de Cordova, C.A.S.; Charao, C.C.T.; Rodrigues de Lima, V.; Creczynski-Pasa, T.B. Melatonin protects against pro-oxidant enzymes and reduces lipid peroxidation in distinct membranes induced by the hydroxyl and ascorbyl radicals and by peroxynitrite. J. Pineal Res. 2003, 35, $262-268$. [CrossRef]

39. Reiter, R.J.; Poeggeler, B.; Tan, D.X.; Chen, L.; Manchester, L.; Guerrero, J. Antioxidant capacity of melatonin. A novel action not requiring a receptor. Neuroendocr. Lett. 1993, 15, 103-116.

40. Weeda, S.; Zhang, N.; Zhao, X.; Ndip, G.; Guo, Y.D.; Buck, G.; Fu, C.; Ren, S. Arabidopsis transcriptome analysis reveals key roles of melatonin in plant defense systems. PLoS ONE 2014, 9, e93462. [CrossRef]

41. Arnao, M.B.; Hernández-Ruiz, J. Melatonin: A new plant hormone and/or a plant master regulator? Trends Plant Sci. 2019, 24, 38-48. [CrossRef]

42. Fischer, T.W.; Kleszcynski, K.; Hardkop, L.H.; Kruse, N.; Zillikens, D. Melatonin enhances antioxidative enzyme gene expression (CAT, GPx, SOD), prevents their UVR-induced depletion, and protects against the formation of DNA damage in ex vivo human skin. J. Pineal Res. 2013, 54, 303-312. [CrossRef] [PubMed]

43. Arnao, M.B. Phytomelatonin: Discovery, content, and role in plants. Adv. Bot. 2014, 2014, e815769. [CrossRef]

44. Arnao, M.B.; Hernández-Ruiz, J. Functions of melatonin in plants: A review. J. Pineal Res. 2015, 59, $133-150$. [CrossRef] [PubMed]

45. Arnao, M.B.; Hernández-Ruiz, J. Growth activity, rooting capacity, and tropism: Three auxinic precepts fulfilled by melatonin. Acta Physiol. Plant 2017, 39, 127. [CrossRef]

46. Arnao, M.B.; Hernández-Ruiz, J. Melatonin in its relationship to plant hormones. Ann. Bot. 2018, 121, 195-207. [CrossRef] [PubMed]

47. Hernández-Ruiz, J.; Arnao, B.M. Relationship of melatonin and salicylic acid in biotic/abiotic plant stress responses. Agronomy 2018, 8, 33. [CrossRef]

48. Arnao, M.B.; Hernández-Ruiz, J. The multi-regulatory properties of melatonin in plants. In Neurotransmitters in Plants; Roshchina, V.V., Ramakrishna, A., Eds.; Taylor \& Francis-CRC: New York, NY, USA, 2018; pp. 71-101.

49. Sharif, R.; Xie, C.; Zhang, H.; Arnao, M.B.; Ali, M.; Ali, Q.; Muhammad, I.; Shalmani, A.; Nawaz, M.; Chen, P.; et al. Melatonin and its effects on plant systems. Molecules 2018, 23, 2352. [CrossRef]

50. Wei, J.; Li, D.; Zhang, J.; Shan, C.; Rengel, Z.; Song, Z.; Chen, Q. Phytomelatonin receptor PMTR1-mediated signaling regulates stomatal closure in Arabidopsis thaliana. J. Pineal Res. 2018, 65, e12500. [CrossRef]

51. Arnao, M.B.; Hernández-Ruiz, J. Melatonin and reactive oxygen and nitrogen species: A model for the plant redox network. Melatonin Res. 2019, 2, 152-168. [CrossRef]

52. Tan, D.X.; Manchester, L.C.; Di Mascio, P.; Martinez, G.R.; Prado, F.M.; Reiter, R.J. Novel rhythms of N-acetyl-N-formyl-5-methoxykynuramine and its precursor melatonin in water hyacinth: Importance for phytoremediation. FASEB J. 2007, 21, 1724-1729. [CrossRef]

53. Tan, D.X.; Manchester, L.C.; Helton, P.; Reiter, R.J. Phytoremediative capacity of plants enriched with melatonin. Plant Signal. Behav. 2007, 2, 514-516. [CrossRef] [PubMed] 
54. Tang, Y.; Lin, L.; Xie, Y.; Liu, J.; Sun, G.; Li, H.; Liao, M.; Wang, Z.; Liang, D.; Xia, H.; et al. Melatonin affects the growth and cadmium accumulation of Malachium aquaticum and Galinsoga parviflora. Int. J. Phytoremediation 2018, 20, 295-300. [CrossRef] [PubMed]

55. Lin, L.; Li, J.; Chen, F.; Liao, M.; Tang, Y.; Liang, D.; Xia, H.; Lai, Y.; Wang, X.; Chen, C.; et al. Effects of melatonin on the growth and cadmium characteristics of Cyphomandra betacea seedlings. Environ. Monit. Assess. 2018, 190, 119. [CrossRef] [PubMed]

56. Li, M.Q.; Hasan, M.; Li, C.X.; Ahammed, G.J.; Xia, X.J.; Shi, K.; Zhou, Y.H.; Reiter, R.J.; Yu, J.Q.; Xu, M.X.; et al. Melatonin mediates selenium-induced tolerance to cadmium stress in tomato plants. J. Pineal Res. 2016, 61, 291-302. [CrossRef]

57. Gu, Q.; Chen, Z.; Yu, X.; Cui, W.; Pan, J.; Zhao, G.; Xu, S.; Wang, R.; Shen, W. Melatonin confers plant tolerance against cadmium stress via the decrease of cadmium accumulation and reestablishment of microRNA-mediated redox homeostasis. Plant Sci. 2017, 261, 28-37. [CrossRef]

58. Lee, K.; Back, K. Overexpression of rice serotonin N-acetyltransferase 1 in transgenic rice plants confers resistance to cadmium and senescence and increases grain yield. J. Pineal Res. 2017, 62, e12392. [CrossRef]

59. Lee, H.Y.; Back, K. Cadmium disrupts subcellular organelles, including chloroplasts, resulting in melatonin induction in plants. Molecules 2017, 22, 1791. [CrossRef]

60. Hasan, M.; Ahammed, G.J.; Yin, L.; Shi, K.; Xia, X.; Zhou, Y.; Yu, J.; Zhou, J. Melatonin mitigates cadmium phytotoxicity through modulation of phytochelatins biosynthesis, vacuolar sequestration and antioxidant potential in Solanum lycopersicum L. Front. Plant Sci. 2015, 6, 601. [CrossRef]

61. Cai, S.Y.; Zhang, Y.; Xu, Y.P.; Qi, Z.Y.; Li, M.Q.; Ahammed, G.J.; Xia, X.J.; Shi, K.; Zhou, Y.H.; Reiter, R.J.; et al. HsfA1a upregulates melatonin biosynthesis to confer cadmium tolerance in tomato plants. J. Pineal Res. 2017, 62, e12387. [CrossRef]

62. Umapathi, M.; Kalarani, M.; Udhaya Bharathi, M.; Kalaiselvi, P. Cadmium induced stress mitigation in tomato by exogenous melatonin. Int. J. Pure App. Biosci. 2018, 6, 903-909. [CrossRef]

63. Hasan, M.; Ahammed, G.J.; Sun, S.; Li, M.; Yin, H.; Zhou, J. Melatonin inhibits cadmium translocation and enhances plant tolerance by regulating sulfur uptake and assimilation in Solanum lycopersicum L. J. Agric. Food Chem. 2019, 67, 10563-10576. [CrossRef] [PubMed]

64. Ni, J.; Wang, Q.; Shah, A.F.; Liu, W.; Wang, D.; Huang, S.; Fu, S.; Wu, L. Exogenous melatonin confers cadmium tolerance by counterbalancing the hydrogen peroxide homeostasis in wheat seedlings. Molecules 2018, 23, 799. [CrossRef] [PubMed]

65. Kaya, C.; Okant, M.; Ugurlar, F.; Alyemeni, M.N.; Ashraf, M.; Ahmad, P. Melatonin-mediated nitric oxide improves tolerance to cadmium toxicity by reducing oxidative stress in wheat plants. Chemosphere 2019, 225, 627-638. [CrossRef] [PubMed]

66. Xiang, G.; Lin, L.; Liao, M.; Tang, Y.; Liang, D.; Xia, H.; Wang, J.; Wang, X.; Sun, G.; Zhang, H.; et al. Effects of melatonin on cadmium accumulation in the accumulator plant Perilla frutescens. Chem. Ecol. 2019, 35, 553-562. [CrossRef]

67. Hodzic, E.; Balaban, M.; Suskalo, N.; Galijasevic, S.; Hasanagic, D.; Kukavica, B. Antioxidative response of Melissa officinalis L. and Valeriana officinalis L. leaves exposed to exogenous melatonin and excessive zinc and cadmium level. J. Serb. Chem. Soc. 2018, 84, 70. [CrossRef]

68. Posmyk, M.M.; Kuran, H.; Marciniak, K.; Janas, K.M. Presowing seed treatment with melatonin protects red cabbage seedlings against toxic copper ion concentrations. J. Pineal Res. 2008, 45, 24-31. [CrossRef]

69. Cao, Y.Y.; Qi, C.D.; Li, S.; Wang, Z.; Wang, X.; Wang, J.; Ren, S.; Li, X.; Zhang, N.; Guo, Y.D. Melatonin alleviates copper toxicity via improving copper sequestration and ROS scavenging in Cucumber. Plant Cell Physiol. 2018, 60, 562-574. [CrossRef]

70. Zuo, Z.; Sun, L.; Wang, T.; Miao, P.; Zhu, X.; Liu, S.; Song, F.; Mao, H.; Li, X. Melatonin improves the photosynthetic carbon assimilation and antioxidant capacity in wheat exposed to nano-ZnO stress. Molecules 2017, 22, 1727. [CrossRef]

71. Zhang, J.; Zeng, B.; Mao, Y.; Kong, X.; Wang, X.; Yang, Y.; Zhang, J.; Xu, J.; Rengel, Z.; Chen, Q. Melatonin alleviates aluminium toxicity through modulating antioxidative enzymes and enhancing organic acid anion exudation in soybean. Funct. Plant Biol. 2017, 44, 961-968. [CrossRef]

72. Zhang, J.; Li, D.; Wei, J.; Ma, W.; Kong, X.; Rengel, Z.; Chen, Q. Melatonin alleviates aluminum-induced root growth inhibition by interfering with nitric oxide production in Arabidopsis. Environ. Exp. Bot. 2019, 161, 157-165. [CrossRef] 
73. Okant, M.; Kaya, C. The role of endogenous nitric oxide in melatonin-improved tolerance to lead toxicity in maize plants. Environ. Sci. Pollut. Res. 2019, 26, 11864-11874. [CrossRef] [PubMed]

74. Xie, C.; Xiong, X.; Huang, Z.; Sun, L.; Ma, J.; Cai, S.; Yu, F.; Zhong, W.; Chen, S.; Li, X. Exogenous melatonin improves lead tolerance of bermudagrass through modulation of the antioxidant defense system. Int. J. Phytoremediation 2018, 20, 1408-1417. [CrossRef] [PubMed]

75. Nawaz, M.A.; Jiao, Y.; Chen, C.; Shireen, F.; Zheng, Z.; Imtiaz, M.; Bie, Z.; Huang, Y. Melatonin pretreatment improves vanadium stress tolerance of watermelon seedlings by reducing vanadium concentration in the leaves and regulating melatonin biosynthesis and antioxidant-related gene expression. J. Plant Physiol. 2018, 220, 115-127. [CrossRef] [PubMed]

76. Sarafi, E.; Tsouvaltzis, P.; Chatzissavvidis, C.; Siomos, A.; Therios, I. Melatonin and resveratrol reverse the toxic effect of high boron (B) and modulate biochemical parameters in pepper plants (Capsicum annuum L.). Plant Physiol. Biochem. 2017, 112, 173-182. [CrossRef] [PubMed]

77. Moussa, H.R.; Algamal, S.M.A. Does exogenous application of melatonin ameliorate boron toxicity in spinach plants? Int. J. Veg. Sci. 2017, 23, 233-245. [CrossRef]

78. Yadu, B.; Chandrakar, V.; Meena, R.K.; Poddar, A.; Keshavkant, S. Spermidine and melatonin attenuate fluoride toxicity by regulating gene expression of antioxidants in Cajanus cajan L. J. Plant Growth Regul. 2018, 37, 1113-1126. [CrossRef]

79. Gong, X.; Shi, S.; Dou, F.; Song, Y.; Ma, F. Exogenous melatonin alleviates alkaline stress in Malus hupehensis Rehd. by regulating the biosynthesis of polyamines. Molecules 2017, 22, 1542. [CrossRef]

80. Liu, N.; Jin, Z.; Wang, S.; Gong, B.; Wen, D.; Wang, X.; Wei, M.; Shi, Q. Sodic alkaline stress mitigation with exogenous melatonin involves reactive oxygen metabolism and ion homeostasis in tomato. Sci. Hortic. 2015, 181, 18-25. [CrossRef]

81. Yan, Y.; Jing, X.; Tang, H.; Li, X.; Gong, B.; Shi, Q. Using transcriptome to discover a novel melatonin-induced sodic alkaline stress resistant pathway in Solanum lycopersicum L. Plant Cell Physiol. 2019, 60, 2051-2064. [CrossRef]

82. Debnath, B.; Hussain, M.; Irshad, M.; Mitra, S.; Li, M.; Liu, S.; Qiu, D. Exogenous melatonin mitigates acid rain stress to tomato plants through modulation of leaf ultrastructure, photosynthesis and antioxidant potential. Molecules 2018, 23, 388. [CrossRef]

83. Kaya, C.; Higgs, D.; Ashraf, M.; Alyemeni, M.; Ahmad, P. Integrative roles of nitric oxide and hydrogen sulfide in melatonin-induced tolerance of pepper (Capsicum annuum L.) plants to iron deficiency and salt stress alone or in combination. Physiol. Plant. [CrossRef]

84. Zhou, C.; Liu, Z.; Zhu, L.; Ma, Z.; Wang, J.; Zhu, J. Exogenous melatonin improves plant iron deficiency tolerance via increased accumulation of polyamine-mediated nitric oxide. Int. J. Mol. Sci. 2016, 17, 1777. [CrossRef] [PubMed]

85. Hasn, M.; Liu, C.X.; Pan, Y.T.; Ahammed, G.J.; Qi, Z.Y.; Zhou, J. Melatonin alleviates low-sulfur stress by promoting sulfur homeostasis in tomato plants. Sci. Rep. 2018, 8, 10182. [CrossRef] [PubMed]

86. Qiao, Y.; Yin, L.; Wang, B.; Ke, Q.; Deng, X.; Wang, S. Melatonin promotes plant growth by increasing nitrogen uptake and assimilation under nitrogen deficient condition in winter wheat. Plant Physiol. Biochem. 2019, 139, 342-349. [CrossRef] [PubMed]

87. Zhang, R.; Sun, Y.; Liu, Z.; Jin, W.; Sun, Y. Effects of melatonin on seedling growth, mineral nutrition, and nitrogen metabolism in cucumber under nitrate stress. J. Pineal Res. 2017, 62, e12403. [CrossRef] [PubMed]

88. Li, J.; Li, Y.; Tian, Y.; Qu, M.; Zhang, W.; Gao, L. Melatonin has the potential to alleviate cinnamic acid stress in cucumber seedlings. Front. Plant Sci. 2017, 8, 1193. [CrossRef]

89. Park, S.; Lee, D.E.; Jang, H.; Byeon, Y.; Kim, Y.S.; Back, K. Melatonin-rich transgenic rice plants exhibit resistance to herbicide-induced oxidative stress. J. Pineal Res. 2013, 54, 258-263. [CrossRef]

90. Zhang, S.; Zheng, X.; Reiter, R.J.; Feng, S.; Wang, Y.; Liu, S.; Jin, L.; Li, Z.; Datla, R.; Ren, M. Melatonin attenuates potato late blight by disrupting cell growth, stress tolerance, fungicide susceptibility and homeostasis of gene expression in Phytophthora infestans. Front. Plant Sci. 2017, 8, 1993. [CrossRef]

91. Szafranska, K.; Reiter, R.J.; Posmyk, M.M. Melatonin improves the photosynthetic apparatus in pea leaves stressed by paraquat via chlorophyll breakdown regulation and its accelerated de novo synthesis. Front. Plant Sci. 2017, 8, 878. [CrossRef] 
92. Yan, Y.; Sun, S.; Zhao, N.; Yang, W.; Shi, Q.; Gong, B. COMT1 overexpression resulting in increased melatonin biosynthesis contributes to the alleviation of carbendazim phytotoxicity and residues in tomato plants. Environ. Pollut. 2019, 252, 51-61. [CrossRef]

93. Posmyk, M.M.; Balabusta, M.; Wieczorek, M.; Sliwinska, E.; Janas, K.M. Melatonin applied to cucumber (Cucumis sativus L.) seeds improves germination during chilling stress. J. Pineal Res. 2009, 46, 214-223. [CrossRef]

94. Imtiaz, M.; Rizwan, M.S.; Xiong, S.; Li, H.; Ashraf, M.; Shahzad, S.M.; Shahzad, M.; Rizwan, M.; Tu, S. Vanadium, recent advancements and research prospects: A review. Environ. Int. 2015, 80, 79-88. [CrossRef] [PubMed]

95. Imtiaz, M.; Rizwan, M.S.; Mushtaq, M.A.; Yousaf, B.; Ashraf, M.; Ali, M.; Yousuf, A.; Rizwan, M.; Din, M.; Dai, Z.; et al. Interactive effects of vanadium and phosphorus on their uptake, growth and heat shock proteins in chickpea genotypes under hydroponic conditions. Environ. Exp. Bot. 2017, 134, 72-81. [CrossRef]

96. Yadu, B.; Chandrakar, V.; Keshavkant, S. Responses of plants towards fluoride: An overview of oxidative stress and defense mechanisms. Fluoride 2016, 49, 293-302.

97. Zhu, J.K. Abiotic stress signaling and responses in plants. Cell 2016, 167, 313-324. [CrossRef] [PubMed]

98. Zhang, S.; Liu, S.; Zhang, J.; Reiter, R.J.; Wang, Y.; Qiu, D.; Luo, X.; Khalid, A.R.; Wang, H.; Feng, L.; et al. Synergistic anti-oomycete effect of melatonin with a biofungicide against oomycetic black shank disease. $J$. Pineal Res. 2018, 65, e12492. [CrossRef]

99. Arnao, M.B.; Hernández-Ruiz, J. Growth conditions determine different melatonin levels in Lupinus albus L. J. Pineal Res. 2013, 55, 149-155. [CrossRef]

100. Arnao, M.B.; Hernández-Ruiz, J. Chemical stress by different agents affects the melatonin content of barley roots. J. Pineal Res. 2009, 46, 295-299. [CrossRef]

101. Arnao, M.B.; Hernández-Ruiz, J. Growth conditions influence the melatonin content of tomato plants. Food Chem. 2013, 138, 1212-1214. [CrossRef]

102. Boccalandro, H.E.; Gonzalez, C.V.; Wunderlin, D.A.; Silva, M.F. Melatonin levels, determined by LC-ESI-MS/MS, fluctuate during the day/night cycle in Vitis vinifera cv Malbec: Evidence of its antioxidant role in fruits. J. Pineal Res. 2011, 51, 226-232. [CrossRef]

103. Zhao, Y.; Tan, D.X.; Lei, Q.; Chen, H.; Wang, L.; Li, Q.T.; Gao, Y.; Kong, J. Melatonin and its potential biological functions in the fruits of sweet cherry. J. Pineal Res. 2013, 55, 79-88. [CrossRef]

104. Arnao, M.B.; Hernández-Ruiz, J. Melatonin: Plant growth regulator and/or biostimulator during stress? Trends Plant Sci. 2014, 19, 789-797. [CrossRef] [PubMed]

105. Arnao, M.B.; Hernández-Ruiz, J. Melatonin as a chemical substance or as phytomelatonin rich-extracts for use as plant protector and/or biostimulant in accordance with EC legislation. Agronomy 2019, 9, 570. [CrossRef]

106. Shi, H.; Jiang, C.; Ye, T.; Tan, D.; Reiter, R.J.; Zhang, H.; Liu, R.; Chan, Z. Comparative physiological, metabolomic, and transcriptomic analyses reveal mechanisms of improved abiotic stress resistance in bermudagrass [Cynodon dactylon (L). Pers.] by exogenous melatonin. J. Exp. Bot. 2015, 66, 681-694. [CrossRef] [PubMed]

107. Wei, W.; Li, Q.; Chu, Y.-N.; Reiter, R.J.; Yu, X.M.; Zhu, D.H.; Zhang, W.K.; Ma, B.; Lin, Q.; Zhang, J.S.; et al. Melatonin enhances plant growth and abiotic stress tolerance in soybean plants. J. Exp. Bot. 2015, 66, 695-707. [CrossRef]

108. Erdal, S. Melatonin promotes plant growth by maintaining integration and coordination between carbon and nitrogen metabolisms. Plant Cell Rep. 2019, 38, 1001-1012. [CrossRef]

109. Liang, B.; Ma, C.; Zhang, Z.; Wei, Z.; Gao, T.; Zhao, Q.; Ma, F.; Li, C. Long-term exogenous application of melatonin improves nutrient uptake fluxes in apple plants under moderate drought stress. Environ. Exp. Bot. 2018, 155, 650-661. [CrossRef]

110. Liang, D.; Shen, Y.; Ni, Z.; Wang, Q.; Lei, Z.; Xu, N.; Deng, Q.; Lin, L.; Wang, J.; Lv, X.; et al. Exogenous melatonin application delays senescence of kiwifruit leaves by regulating the antioxidant capacity and biosynthesis of flavonoids. Front. Plant Sci. 2018, 9, 426. [CrossRef]

111. Zhang, N.; Sun, Q.; Li, H.; Cao, Y.; Zhang, H.; Li, S.; Zhang, L.; Qi, Y.; Ren, S.; Zhao, B.; et al. Melatonin improved anthocyanin accumulation by regulating gene expressions and resulted in high reactive oxygen species scavenging capacity in cabbage. Front. Plant Sci. 2016, 7, 197. [CrossRef] 
112. Sun, Q.; Zhang, N.; Wang, J.; Cao, Y.; Li, X.; Zhang, H.; Zhang, L.; Tan, D.X.; Guo, Y.D. A label-free differential proteomics analysis reveals the effect of melatonin on promoting fruit ripening and anthocyanin accumulation upon postharvest in tomato. J. Pineal Res. 2016, 61, 138-153. [CrossRef]

113. Zhang, Q.; Liu, X.; Zhang, Z.; Liu, N.; Li, D.; Hu, L. Melatonin improved waterlogging tolerance in alfalfa (Medicago sativa) by reprogramming polyamine and ethylene metabolism. Front. Plant Sci. 2019, 10, 44. [CrossRef]

114. Shi, H.; Chan, Z. The Cysteine2/Histidine2-type transcription factor ZINC FINGER OF ARABIDOPSIS THALIANA 6-activated C-REPEAT-BINDING FACTOR pathway is essential for melatonin-mediated freezing stress resistance in Arabidopsis. J. Pineal Res. 2014, 57, 185-191. [CrossRef] [PubMed]

115. Shi, H.; Tan, D.X.; Reiter, R.J.; Ye, T.; Yang, F.; Chan, Z. Melatonin induces class A1 heat shock factors (HSFA1s) and their possible involvement of thermotolerance in Arabidopsis. J. Pineal Res. 2015, 58, 335-342. [CrossRef] [PubMed]

116. Shi, H.; Qian, Y.; Tan, D.X.; Reiter, R.J.; He, C. Melatonin induces the transcripts of CBF/DREB1s and their involvement in both abiotic and biotic stresses in Arabidopsis. J. Pineal Res. 2015, 59, 334-342. [CrossRef] [PubMed]

117. Yang, W.J.; Du, Y.T.; Zhou, Y.B.; Chen, J.; Xu, Z.S.; Ma, Y.Z.; Chen, M.; Min, D.H. Overexpression of TaCOMT improves melatonin production and enhances drought tolerance in transgenic Arabidopsis. Int. J. Mol. Sci. 2019, 20, 652. [CrossRef] [PubMed]

118. Li, X.; Tan, D.X.; Jiang, D.; Liu, F. Melatonin enhances cold tolerance in drought-primed wild-type and abscisic acid-deficient mutant barley. J. Pineal Res. 2016, 61, 328-339. [CrossRef]

119. Fan, J.; Hu, Z.; Xie, Y.; Chan, Z.; Chen, K.; Amombo, E.; Chen, L.; Fu, J. Alleviation of cold damage to photosystem II and metabolisms by melatonin in Bermudagrass. Front. Plant Sci. 2015, 6, 925. [CrossRef]

120. Wei, Y.; Chang, Y.; Zeng, H.; Liu, G.; He, C.; Shi, H. RAV transcription factors are essential for disease resistance against cassava bacterial blight via activation of melatonin biosynthesis genes. J. Pineal Res. 2018, 64, e12454. [CrossRef]

121. Li, C.; Liang, D.; Chang, C.; Jia, D.; Ma, F. Melatonin mediates the regulation of ABA metabolism, free-radical scavenging, and stomatal behavior in two Malus species under drought stress. J. Exp. Bot. 2015, 66, 669-680. [CrossRef]

122. Byeon, Y.; Lee, H.Y.; Hwang, O.J.; Lee, H.J.; Lee, K.; Back, K. Coordinated regulation of melatonin synthesis and degradation genes in rice leaves in response to cadmium treatment. J. Pineal Res. 2015, 58, 470-478. [CrossRef]

123. Wei, Y.; Zeng, H.; Hu, W.; Chen, L.; He, C.; Shi, H. Comparative transcriptional profiling of melatonin synthesis and catabolic genes indicates the possible role of melatonin in developmental and stress responses in rice. Front. Plant Sci. 2016, 7, 676. [CrossRef]

124. Zhang, J.; Li, H.; Xu, B.; Li, J.; Huang, B. Exogenous melatonin suppresses dark-induced leaf senescence by activating the superoxide dismutase-catalase antioxidant pathway and down-regulating chlorophyll degradation in excised leaves of perennial ryegrass (Lolium perenne L.). Front. Plant Sci. 2016, 7, 1500. [CrossRef] [PubMed]

125. Mukherjee, S.; David, A.; Yadav, S.; Baluska, F.; Bhatla, S.C. Salt stress-induced seedling growth inhibition coincides with differential distribution of serotonin and melatonin in sunflower seedling roots and cotyledons. Physiol. Plant 2014, 152, 714-728. [CrossRef] [PubMed]

126. Ahammed, G.J.; Xu, W.; Liu, A.; Chen, S. Endogenous melatonin deficiency aggravates high temperature-induced oxidative stress in Solanum lycopersicum L. Environ. Exp. Bot. 2019, 161, 303-311. [CrossRef]

127. Jiao, J.; Ma, Y.; Chen, S.; Liu, C.; Song, Y.; Qin, Y.; Yuan, C.; Liu, Y. Melatonin-producing endophytic bacteria from grapevine roots promote the abiotic stress-induced production of endogenous melatonin in their hosts. Front. Plant Sci. 2016, 7, 1387. [CrossRef] [PubMed]

(C) 2019 by the authors. Licensee MDPI, Basel, Switzerland. This article is an open access article distributed under the terms and conditions of the Creative Commons Attribution (CC BY) license (http://creativecommons.org/licenses/by/4.0/). 